\title{
'BEING SHED FOR YOU/MANY': TIME-SENSE AND CONSEQUENCES IN THE SYNOPTIC CUP CITATIONS
}

\author{
Lynne C. Boughton
}

\begin{abstract}
Summary
All three Synoptic accounts of the Last Supper describe a cup offering in which Jesus refers to an act done for beneficiaries. This act, expressed by the present

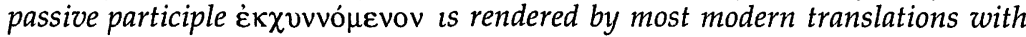
present tense verb forms and has been treated by source and historical critical researchers as denoting a 'pouring out' taking place at the supper table. Nevertheless, biblical Greek usage indicates that a participle's time-sense was determined not by tense but by verbal aspect derived from content. If, as this

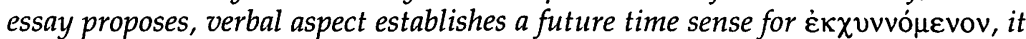
would indicate that the Synoptic Gospels, like John's Gospel, are describing a Passover supper on the eve of the Day of Preparation and portraying Jesus as speaking of the shedding of blood on the cross, not the libation at the table.
\end{abstract}

\section{Introduction}

According to the Synoptic Gospels and Paul, Jesus enjoined those with whom he shared his Last Supper to drink from an offered cup. In Matthew 26:28/Mark 14:24 Jesus declares that 'this is my blood of the covenant' and refers to an act of 'being poured out for many'. In Luke 22:20 he speaks of 'this cup, the new covenant in my blood' and of an act of 'being poured out for you'. 1 Corinthians 11:25 parallels Luke in reporting that Jesus said 'this cup is the new covenant in my blood' but, unlike all three Synoptic Gospels, cites no reference to a pouring out or to beneficiaries of that act. Exegetes exploring the meaning of the citations, as well as critical scholars attempting to determine the origin and original wording, have examined the phrases 'my blood of the covenant' and 'new 
covenant in my blood', as well as the designations 'many' and 'you'. Nevertheless, the act of being poured out or shed, expressed in the Synoptic Gospels by the present passive participle $\dot{\varepsilon} \kappa \chi v v$ ó $\mu \varepsilon v o v$, has been ignored by critical scholars and discussed only by a few exegetes and translators. Certainly, the pouring out of the cup's content at the supper connotes the shedding of blood on the cross. What deserves further consideration is whether the Synoptic authors (or a source

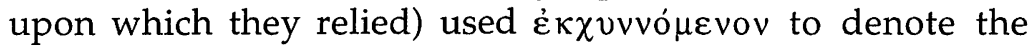
present act of drinking or the anticipated act of bloodshed. In other words, does this participle convey a present or a future 'time-sense'?

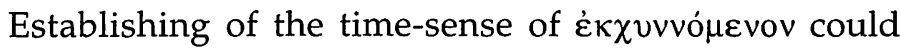
assist source-critical and historical critical researchers in determining the origin of the cup-citations. If the participle denoted a pouring out at supper, it would support the hypothesis that the cup-citation originated in the Apostolic era to explain how a meal libation common to Diaspora households could be used in recalling Jesus' bloodshed. If, however, the participle denoted a pouring out that has not yet taken place, it would suggest that the Synoptic Gospels preserve a time-sense consistent with an historical Last Supper at which Jesus linked his expectation of death with an impending Passover sacrifice.

The exegetical implications of the participle's time sense are also important. Whether $\dot{\varepsilon} \kappa \chi v v v o$ ó $\mu v v_{\nu}$ should be understood as denoting the action taking place at table or on the cross was vigorously debated in the sixteenth century. Swiss Reformers, who held that the Last Supper and its commemorations 'symbolised' the salvation of those for whom Christ died, and Calvinists and Strassburgians, who believed that the historical and liturgical suppers 'spiritually nourished'

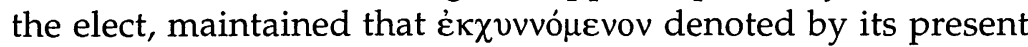
tense what is being poured out at supper. Martin Luther, on the other hand, although accepting limited atonement, rejected spiritual and symbolic interpretations of the supper. According to Luther the context, rather than the tense, of the participle conveyed time-sense. He maintained that, although the cited words made clear that those who drank from the cup literally consumed the blood of Christ, the wording also indicated that 
the act of pouring out or shedding that made this possible would not take place until the next day. Thus Luther translated $\dot{\varepsilon} \kappa \chi \cup \vee v o ́ \mu \varepsilon v o v$ as 'ergossen wird' (will be poured out). Catholic exegetes also held that the act of pouring out literally took place on the cross, not symbolically at the table. Their argument, however, emphasised that a future time-sense was affirmed by texts of the Latin Vulgate, which contains the future passive effundetur (Matthew/Mark) and fundetur (Luke). Moreover, they held that this time-sense not only supported the doctrine of universal atonement (and conditional salvation) but also identified the cup's content as 'substantially' and objectively the blood of Jesus, 'sacrificially' offered and consumed at the historical and sacramental suppers. ${ }^{1}$

But by the end of the sixteenth century, almost all scholars accepted a present time-sense for the Greek participle. Among English translators, the Catholic authors of the DouaiReims New Testament (1582), although rendering the cupcitation as 'shall be shed' to conform to the Vulgate, declared in a preface that the Greek text's present time-sense more easily supported transubstantiation. ${ }^{2}$ Likewise, English translators influenced by Luther, with the exception of Miles Coverdale whose work of 1535 was based on a Vulgate text and used

\footnotetext{
${ }^{1}$ For doctrinal positions see J. Calvin, Institutes of the Christian Religion [1559] ed. J. McNeill, trans. F.L. Battles (2 vols.; Philadelphia: Westminster, 1960) 2.1359-1411, 1431-36 (4.17.1-34; 4.18.3-6); 'Decrees of the Council of Trent [1546-1563]', in H. Denzinger and A. Schönmetzer, Enchiridion Symbolorum (36th ed.; Barcinone: Herder, 1976) \#1506 and \#1743; M. Luther, Biblia [1545] (repr.; Stuttgart: Wuttembergischen Bibelanstalt, 1967); and 'Confession Concerning Christ's Supper', [1528] in Luther's Works (55 vols., Philadelphia: Muhlenberg, 1961) 37.331. See also F. Clark, The Eucharistic Sacrifice and the Reformation (London: Darton, Longman, \& Todd, 1960); A. Barclay, The Protestant Doctrine of the Lord's Supper: A Study in the Eucharistic Teaching of Luther, Zwingli, and Calvin (Glasgow: Jackson/ Wylie, 1927); K. McDonnell, John Calvin: The Church and the Eucharist (Princeton: Princeton University, 1967) 223-48. For distinctions between Swiss (U. Zwingli) and Strasbourg (M. Bucer) Reformers see C.H. Smyth, Cranmer and the Reformation Under Edward VI (1926; Westport: Greenwood, 1970) $17-25$.

2The New Testament Translated out of the Latin Vulgate...and First Published by the English College of Rheims, Anno 1582 (New York: Leavitt, 1834), Preface, 22 (\#35).
} 


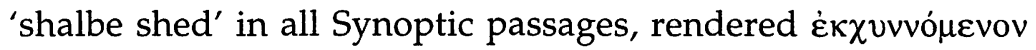
with a present tense either in Mark (as did the William Tyndale [1526] and 'Thomas Matthew' [1537] Bibles) or in all the Synoptic Gospels (as did the 'Great' [1539], Taverner [1539], Geneva [1560], and Bishops' [1568] Bibles). ${ }^{3}$

At this point, some may question whether $\dot{\varepsilon} \kappa \chi \cup v v o ́ \mu \varepsilon v o v$, as a present-tense participle, could denote anything other than a present action. Respected and widely circulated English translations produced in the seventeenth through twentieth centuries (e.g., AV/KJV, NIV, RSV, NEB, AS,

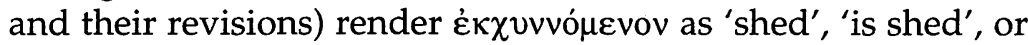
'is poured out'. Only those translators who, in producing versions for Catholic use (e.g., Knox, JB [French and English], NAB) consulted the standard Vulgate text (the SixtoClementine Vulgate [1592]) and accepted its future passive effundetur/ fundetur as a record of Jerome's usage, chose verb forms denoting a future pouring out. Even some who worked primarily with the Vulgate, as did the Confraternity revisers (1941) of the Douai-Reims, used 'is being shed' on grounds that the present tense of the Greek participle, not the tense of its Latin translation, should determine time-sense in vernacular renderings. Among those translating from the Vulgate, only Richard Simon in his French version (1702) and the NAB revisers (1986) declared that Greek usage itself, not just the authority of the Vulgate, indicated that $\dot{\varepsilon} \kappa \chi v v v o$ ó $\varepsilon v o v$ denoted futurity. ${ }^{4}$ In 1979, however, acceptance of a present-tense rendering was furthered by publication of the Nova Vulgata Bibliorum. Because the Nova Vulgata Bibliorum was published as

${ }^{3}$ Tyndale's New Testament, Translated from the Greek (1534 edition), ed. D. Daniell (New Haven: Yale, 1989), and Geneva Bible: A Facsimile of the 1560 Edition, ed. L. Berry (Madison: University of Wisconsin, 1969). See [Thomas Matthew] Holy Bible (1537); [Miles Coverdale] Holy Scriptures (1535); Holy [Great] Bible (Whitchurch, 1541); [Richard] Taverner's Bible (Barthelet, 1539); [Bishops'] Holy Bible (1568) Newberry Library, Chicago.

4The Confraternity used 'is being shed' in Matthew/Mark but 'shall be shed' in Luke; see The New Testament: Confraternity Version (New York: Benzinger, 1960) 229; The New American Bible (New York: Catholic Book Publishing, 1986) 59; R. Simon, Le Nouveau Testament de Notre Seigneur Jesus-Christ Traduit sur l'ancienne Edition latine (2 vols.; Trevoux: Ganeau, 1702) 142 n., 238 n., 390 n. 
a correction of the Sixto-Clementine Vulgate, its use of the present passive effunditur/funditur suggests that modern analysis of Vulgate manuscripts reveals that Jerome understood $\dot{\varepsilon} \kappa \chi \cup v v o ́ \mu \varepsilon v o v$ as occurring at the table. 5

But although it seems paradoxical to argue that a present-tense participle indicates, or ever indicated, anything other than a present time-sense, analysis of verbal aspect in biblical Greek and a survey of Patristic-era commentaries and translations suggest that $\dot{\varepsilon} \kappa \chi v v v o$ or vov was used by the Synoptic authors and understood by early readers and translators as denoting an action predicted by, not concurrent with, a cup-offering. The study undertaken here proposes that lexical and syntactical analysis reveals a future time-sense for the 'pouring out' and that this aspect of futurity was not only intended by the Synoptic Gospels but indicates that their attribution of the cited words to Jesus at a supper at Passover records the historical origin of the citation.

This study also proposes that the Synoptic authors have not, as is commonly proposed by those who defend the historicity of the Passover context, placed Jesus' last supper on the evening following the main slaying of Temple lambs on 14 Nisan, but have, like John, recorded a supper on the evening before the slaughter. In that case, a future time-sense for a pouring out that effects a covenant coheres with the $\pi \varepsilon \rho i / i \pi \dot{\varepsilon} \rho$ $\pi \mathrm{o} \lambda \lambda \hat{\omega} \mathrm{v}$ ('for many') of Matthew and Mark, rather than the $\dot{\tau} \pi \dot{\varepsilon} \rho$

${ }^{5}$ Nova Vulgata Bibliorum sacrorum editio (Vatican City: Editrice Vaticana, 1979; 2nd ed. 1986). Cf. Sixto-Clementine Vulgate and Nova Vulgata Bibliorum in Novum Testamentum Graece et Latine, ed. G. Nolli (Vatican City: Editrice Vaticana, 1981). Although the Nova Vulgata Bibliorum is often thought to be the result of text-critical analysis of Vulgate manuscripts, those who produced the Nova Vulgata Bibliorum simply accepted textcritical judgements concerning the content of the Greek text and brought the Latin into line, not with the best Vulgate text copies, but with modern consensus on the meaning of the Greek. Cf. K. Aland and B. Aland, The Text of the New Testament: An Introduction to the Critical Editions and to the Theory and Practice of Modern Textual Criticism (Grand Rapids: Eerdmans, 1989) 190; T. Stramare, 'La neo-Volgata: impresa scientifica e pastorale insieme', EB, n.s. 38 (1979-80) 115-38; and T. Fornberg, 'Textual Criticism and Canon: Some Problems', ST 40/1 (1986) 45-53. 
$\dot{v} \mu \hat{\omega} v$ ('for you') of Luke, and indicates that $\pi \mathrm{o} \lambda \lambda \hat{\omega} v$ originally designated the covenant's beneficiaries.

\section{Historical-Critical Debates}

Historical-critical debates on the origin of the cup-citations coalesce around two competing hypotheses. One is that Paul, who introduces his citation by mentioning the betrayal of Jesus but not the Passover, predates written and oral traditions narrating a Passover context and preserves a pre-Synoptic oral source transmitted, shaped, or even originating in Christian worship. Since Luke, like Paul, cites Jesus as specifying 'this cup', addressing those present as 'you' (implicit in Paul on the basis of the bread-citation in 1 Cor. 11:14), using formulae 'in a like manner' and 'do this in memory of me', and offering bread and wine 'after supper', proponents of this hypothesis conclude that Luke also records liturgical practice. Luke's conformity to Matthew/Mark in mentioning Passover and in citing $\dot{\varepsilon} \kappa \chi \cup \vee v o$ orvov suggest, in this hypothesis, that Luke conflated the liturgical source with later explanatory narratives. ${ }^{6}$

The contrary hypothesis holds that, although Paul cited words used in worship, such worship was based on an older narrative-source or sayings-source that preserved Jesus' reference (at a Passover supper in Jerusalem) to a blood-

${ }^{6}$ That Paul used a liturgised oral source and Mark historicised another oral source is held by W. Marxsen, The Lord's Supper as a Christological Problem (Philadelphia: Fortress, 1970) 5-13; B. Chilton, A Feast of Meanings: Eucharistic Theologies from Jesus through Johannine Circles (NTS 72; Leiden: Brill, 1994) 71; H. Lietzmann, The Mass and the Lord's Supper (Leiden: Brill, 1979) 174; and R. Brown, The Death of the Messiah, (2 vols.; New York: Doubleday, 1993) 1.51. That Paul's source originated in liturgy rather than as a logia is held by R. Bultmann, History of the Synoptic Tradition (Oxford: Blackwell, 1963) 265-67; B. Mack, The Myth of Innocence: Mark and Christian Origins (Philadelphia: Fortress, 1988) 298-304; J. Martos, Doors to the Sacred (Garden City: Doubleday, 1981) 240-41; F.L. Cirlot, The Early Eucharist (London: SPCK, 1939) 22; and J.D.G. Dunn, Unity and Diversity in the New Testament: An Inquiry into the Character of Earliest Christianity (London: SCM, 1977) 161-68. B. Lang proposes that Jesus spoke of bread and wine as 'my body/my blood' so that these would replace ' $m y^{\prime}$ Temple lamb ('The Roots of the Eucharist in Jesus' Praxis', SBL 1992 Seminar Papers, 46772. 
covenant. Proponents of this hypothesis disagree as to whether Luke or Matthew/Mark more accurately preserves this source. Some, noting descriptive elements in Luke (e.g., two cupofferings) that are neither in Paul nor Matthew / Mark, conclude that Luke used a pre-Synoptic narrative that (1) recorded a libation offered after the Passover meal, (2) reflected Jewish sensibilities by citing a request to drink from the 'cup' rather than to drink the 'blood of the covenant', and (3) preserved a Passover idiom, like that recorded in the Mishnah, of referring to acts done 'for you'. Thus Luke combined words traceable to Jesus at Passover with liturgical directives like those known to Paul, whereas Matthew/Mark reworded a source preserving a Passover narrative (or, in some theories of Synoptic relationships, reworded Luke) to focus on redemptive 'blood' rather than on a 'covenant in blood' and on 'many' recipients rather than on 'you' who are at the supper.7

Other proponents of the historicity of the Passover context maintain that Matthew/Mark preserve a historically accurate, pre-liturgical source because they (1) lack formulaic or prescriptive elements, (2) use $\tau \hat{\eta} \varsigma \delta \iota \alpha \theta \dot{\eta} \kappa \eta$ s rather than $\kappa \alpha \iota v \dot{\eta}$ $\delta\llcorner\alpha \theta \dot{\eta} \kappa \eta$, and (3) mention bread and wine being offered 'while eating'. A covenant that is not 'new', reference to 'blood of the covenant' rather than 'covenant in blood', and extension of one meal into another ('while eating') suggest Passover language and practices not only prior to Mishnaic formalisation but also prior to the needs of Gentile Christians for explanatory insertions. If this were the case, Matthew or Mark would preserve, or would be, a primitive source recording events in Jerusalem, whereas Luke would have adapted this source

${ }^{7} \mathrm{H}$. Schürmann holds that Luke used a narrative that cited Jesus (Einer Quellenkritishen Untersuchung des Lukanischen Abendmahlsberichtes, Lk 22.738 [3 vols. in 2; NA 19-20; Munster: Aschendorff, 1953-1957] 2.5-15). Although agreeing with Schürmann that the asymmetry of Luke's bread/ cup-citation and the unusual style of his supper account show use of a pre-liturgical, pre-Synoptic narrative, J. Betz holds that all four citations show liturgical adaptation (Die Eucharistie in der Zeit der griechisden Vaters [2 vols.; Freiburg: Herder, 1955] 1.1-15). J. Kodell proposes on stylistic grounds that Luke preserves the authentic cup citation and Mark the authentic bread citation (The Eucharist in the Nerv Testament [Wilmington: Glazier, 1988] 63-65). 
through liturgical insertions and substitutions (e.g., 'do this', 'new covenant', 'for you') which are also cited by Paul. 8

Those who doubt that any Synoptic supper-narrative preserves the words of Jesus or the context of a Jerusalem Passover and who trace all four citations to the meal-rituals of Diaspora Jewish converts to Christianity, propose that the Synoptic authors, in omitting reference to Mishnaic prescriptions for serving and explaining the Passover, show that they have placed an ordinary meal discourse or benediction into a fabricated Passover context. Defenders of narrative or sayings-source hypotheses dispute this assertion by noting that many practices eventually associated with the Seder were not standardised until they were codified in the written Mishnah in the second century C.E. The Torah's own rules for consumption of the Passover were minimal and included few standardised words or actions. 9

${ }^{8}$ The following scholars hold that Matthew is the earliest source of the supper words and that Mark repeats Matthew, whereas Luke combines Matthew and a liturgical source: B. Orchard and H. Riley, The Order of the Synoptics (Macon: Mercer, 1987) 48-49; I.H. Marshall, Last Supper and Lord's Supper (Grand Rapids: Eerdmans, 1981) 33-35, 161 n. 11; and B. Reicke, Roots of the Synoptic Gospels (Philadelphia: Fortress, 1986) 160-66. The following scholars hold that Mark, as the first Synoptic, cited an oral or written narrative: J. Jeremias, The Eucharistic Words of Jesus (London: SCM, 1966) 169-73; J. Roloff, 'Anfänge der soteriologischen Deutung des Todes Jesu (Mk x.45 und Lk xxii.27)', NTS 19 (1972-73) 38-64; H. Patsch, Abendmahl und Historischer Jesu (Stuttgart: Calwer, 1972) 226-27; and R. Pesch, Das Abendmahl und Jesu Todesverstandnis (QD 80; Freiburg: Herder, 1978) 51-53. K.G. Kuhn holds that Mark used a logia not a narrative ('Über den ursprünglichen Sinn des Abendmahles und sein Verhaltnis zu den Gemeinschaftsmahlen der Sektenschrift', ET 10 [1950-51] 521). A.J.B. Higgins argues that Mark is the earliest written record of words previously transmitted in liturgy (The Lord's Supper in the New Testament [SBT 6; London: SCM, 1952] 24). R.J. Daly doubts that the wording and meaning of Jesus can be recovered ('The Eucharist and Redemption: The Last Supper and Jesus' Understanding of His Death', BTB 11 [1981] 21-27). ${ }^{9}$ The following scholars trace the words to Jesus but at a meal apart from Passover: H. Braun, Jesus of Nazareth: The Man and His Time (Philadelphia: Fortress, 1979) 34-57; Chilton, Feast, 40-45, 93-108; J. Reumann, The Supper of the Lord, the New Testament, Ecumenical Dialogues, and Faith and Order on the Eucharist (Philadelphia: Fortress, 1985) 8-16; X. Leon-Dufour, Sharing the Eucharistic Bread: The Witness of the New Testament (New York: Paulist, 1987) 3-4; and L. Bouyer, Eucharist: Theology and Spirituality of the 
Thus the central historical-critical question is whether Synoptic mention of Passover as the occasion for the cupcitation has historical basis. Scholars have long noted that the Synoptic authors, in identifying the Last Supper with eating 'the Passover' and in placing it, as Mark 14:1 and Luke 22:7 specify, on the 'day of sacrifice', differ from John who places the Last Supper 'before the feast of Passover' on 'evening before the Day of Preparation' and identifies the next morning as initiating the day on which Jesus' opponents plan to 'eat the Passover' (Jn. 13:1-2; 18:28; 19:14). To argue that the Synoptic authors have correctly placed the Last Supper on Passover evening is to reject John's dating. Yet considerable support for the accuracy of John's placement of the supper before the Preparation has been raised by A. Jaubert's observation that on the afternoon of 13 Nisan, about twenty-four hours before the main sacrifice of lambs in the Temple, leavened bread was removed from homes and some Temple lambs were slain for priestly families. That evening, many Judeans held meals honouring the coming Passover. Essenes, who also sacrificed lambs on 13 Nisan, but apart from the Temple, consumed the Passover that same evening. ${ }^{10}$ Thus the dating used by John is reconcilable with the Last Supper taking place, with all the

Eucharistic Prayer (Notre Dame: Notre Dame, 1966) 97-101.

The following scholars hold that the Synoptic Gospels record a Passover seder: H. Strack and P. Billerbeck, Kommentar zum Neuen Testament aus Talmud und Midrasch (4 vols. in 5; München: Beck, 1922-61) 2.843-53; Marshall, Lord's Supper, 57-58; Orchard and Riley, Order, 48-49; M. Black, 'The Arrest and Trial of Jesus and the Date of the Last Supper', in New Testament Essays: Studies in Memory of T. W. Manson, ed. A.J.B. Higgins (Manchester: University Press, 1959) 19-33; Higgins, Lord's Supper, 17; and Jeremias, Eucharistic, 34-35. K.G. Kuhn argues that what was first written in Mark and copied by Matthew was neither an ordinary supper nor a Passover but a Qumran supper ('The Lord's Supper and the Communal Meal at Qumran', in The Scrolls and the Nezv Testament, ed. K. Stendahl [New York: Harper, 1957] 65-93).

${ }^{10}$ La date de la Cene (Paris: Gabalda, 1957) 13-59. See also Black, 'Arrest and Trial', 19-33; T. Preiss, 'Le dernier repas de Jesus, fut-il un repas pascal?', TZ 4 (1948) 81-101; Schürmann, Lukanischen, 1.8-9; and K. Grayston, Dying, We Live: A New Enquiry into the Death of Christ in the New Testament (New York: Oxford, 1990) 203-207. See further, M. Casey, 'The Date of the Passover Sacrifice and Mark 14:12', TynB 48 (1997) 245-47. 
trappings of Passover, on the night before the Day of Preparation.

But a conclusion that John has correctly placed the Last Supper before the main preparation of lambs and before Passover is also reconcilable with the historicity of the Synoptic reference to that supper taking place on Passover if the Synoptic authors, like John, placed the Last Supper on the evening that preceded the main slaying of lambs on 14 Nisan but designated the festival differently. ${ }^{11}$ Synoptic identification of Passover with Unleavened Bread (Mt. 26:17; Mk. 14:12; Lk. 12:7), although absent from John and inconsistent with the Mishnah, is consistent with intertestamental writings. Moreover, the Synoptic report that Jesus directed his disciples to seek out a particular man in Jerusalem to obtain what was needed to eat the Passover meal (Mt. 26:18-19; Mk. 14:12-14; Lk. 22:10) coheres with the practice among city-dwelling Essenes of providing 'necessities' for 'strangers' (Josephus, BJ 2.8.4) and with the possibility that lambs from Essene sacrifices would be among these provisions on the evening before the Day of Preparation.

Accordingly, it is possible that the Synoptic Gospels describe a supper on the evening before the Day of Preparation, and differed from John only in terminology, and that they record a different system of determining the beginning and end of a calendar date. Although the Torah prescribes that the Passover' be slain on 14 Nisan, the manner of determining the beginning and end of a 'day' varied among first-century Judeans (cf. Ex. 12:14-18; Lv. 23:5-6; Dt. 16:4; Jb. 49:1, 10; 11QT $17: 1-10)$. Some considered the evening before the main slaying of lambs to not be part of the Day of Preparation but, instead, to be the evening of the previous 'day' (i.e., 13 Nisan). Others regarded the sunset prior to the Day of Preparation as initiating the 'day' of 14 Nisan, the date specified as Passover. For all Jews, the afternoon of 14 Nisan occasioned the main 'preparation' (slaying) of lambs and sunset occasioned the

${ }^{11}$ Differences between Passover in the era of the Second Temple and after the written Mishnah are noted by G. Dalman, Jesus-Jeschua: Studies in the Gospels (London: SPCK, 1929) 86-96; see particularly Josephus, BJ 2.1.3; 5.3.1. 
eating of 'the Passover'. But for those who believed a day started at sunset, the sunset ending the Day of Preparation initiated the date of 15 Nisan, the 'day' after Passover. If, for the Synoptic authors, a day began at sunset, a meal preceding the Day of Preparation would be on Passover even though the main slaying of lambs had not yet taken place. This would be an appropriate occasion for a discourse concerning blood that was about to be shed.

\section{Lexical and Grammatical Analysis}

Since those holding that the Synoptic Gospels record a Passover context disagree on whether Luke or Matthew/Mark more accurately preserves wording appropriate to that context, one way to analyse the differences is by determining which is more in accord with $\dot{\kappa} \chi \cup v v o$ óvvov. For this task, lexical meaning of

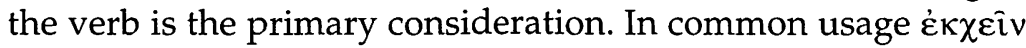
denotes effusion, gushing, spilling, pouring, or shedding fluid (especially blood) in a lavish, indiscriminate, wasteful, and excessive way. The Latin effundo/ fundo has the same range of meanings. ${ }^{12}$ Thus lexically, the subordinate verb in the citations is inappropriate in denoting the serving or consumption of a supper libation, even if that beverage is identified as 'blood'.

In a similar way, syntax, context, and usage also

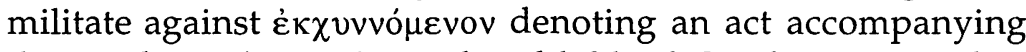
the cited words. In classical and biblical Greek, a participle's time-sense is established by context rather than by tense. Of itself, a participle expresses an aspect of an action (its beginning, duration, completion, or repetition) rather than a point in time at which the action occurs. Aspect is derived from context and, in the case of participles, depends on the

\footnotetext{
12J. Behm, TDNT 2.467-69; cf. H.G. Liddell, R. Scott, H.S. Jones, R. McKenzie, A Greek-English Lexicon (9th ed.; Oxford: Clarendon, 1996) 526. Jeremias, like Behm, notes that the Septuagint uses $\dot{\varepsilon} \kappa \chi \varepsilon i \nu \alpha i \mu \alpha$ only of sacrificial blood (Eucharistic, 222). Chilton points out that $\dot{\varepsilon} \kappa \chi \varepsilon i v$ and cognates are in the Septuagint of Ex. 24:6 (Feast, 87).
} 
relationship of the participle to the finite (main) verb. ${ }^{13}$ As S.E. Porter observes, a participle placed after the verb on which it depends can refer to an act that is concurrent with or subsequent to the action of that main verb.14 Thus context determines whether a present-tense participle denotes an action that overlaps with that of the main verb or one that is 'still to come'. F. Blass and A. Debrunner point out that a participle denoting an act that finalises or completes some objective implies futurity. ${ }^{15}$ Similarly, B.M. Fanning cites examples in the Synoptic Gospels where present, aorist, and other participles communicate, by context, either simultaneity with the main verb (Mt. 3:16; 24:3; Mk. 1:16, 40; Lk. 2:20; 23:10, 26) or acts done customarily by one person or in unison by several (Mt. 2:2; 23:37; Mk. 1:14-15; Lk. 23:5); he concludes that Mk. 14:24 (and presumably Lk. 22:20 and Mt. 26:28, which he assumes are based on Mark) denotes a future 'pouring out'. The contextual suggestion that those present were to drink from 'this' the offered cup, not from their own cups, excludes simultaneity or unison, and indicates that the pouring out is not consumption of the cup's content but a future event. ${ }^{16}$

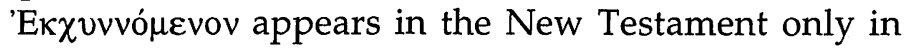
the Synoptic cup-citations and in Matthew 23:35 and Luke 11:50. After mention in Matthew 23:34 and Luke 11:49 that people 'will kill' (future indicative) prophets and others sent by

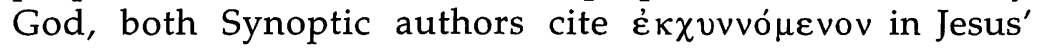
reference to virtuous men who were slain in the past. Although

\footnotetext{
13Zerwick and Smith, Biblical Greek, 129 (\#371); B.M. Fanning, Verbal Aspect in New Testament Greek (Oxford: Clarendon, 1990) 10-11; S.E. Porter, Idioms of the Greek New Testament (2nd ed.; Sheffield: JSOT, 1994) 181-87. 14Porter, Idioms, 188.

${ }_{15}$ Grammatik des neutestamentlichen Griechisch (Göttingen: Vandenhoeck \& Ruprecht, 1954) 209-10 (\#339.2)

16Verbal Aspect, 410-13. See also N. Turner, Syntax, vol. 3 in J.H. Moulton, Grammar of New Testament Greek (3 vols.; Edinburgh: T \& T Clark, 19081963) 79-80; and Jeremias, Eucharistic, 178-79. A grammatical argument for a present time-sense is made by E. Burton, Syntax of the Moods and Tenses in New Testament Greek (Edinburgh: T \& T Clark, 1894) 54-59. Schürmann attributes a present time-sense to $\dot{\varepsilon} \kappa \chi v v v o$ orvov since an act affecting the cup would parallel the present act of breaking bread (Lukanischen, 2.67). Yet the parallel is between breaking the bread and offering the cup, not pouring out of the cup.
} 


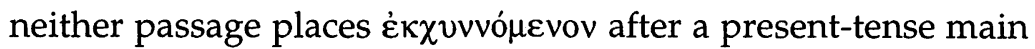
verb (as do the cup-citations), it is interesting that the present passive participle is not used in Matthew 23:35 or Luke 11:50 to denote an action taking place as Jesus speaks. Moreover, the effect of that bloodshed is a future contingency. In Matthew 23:35 it 'shall come' (subjunctive) upon the murderers, and in Luke 11:52 it 'shall be required of this generation'. ${ }^{17}$

That the Synoptic cup-citations denote futurity is also suggested by the fourteenth-century Shem-Tov text of Matthew. Mostly in biblical Hebrew with a few passages and glosses in second-century Mishnaic style, Shem-Tov may be derived from either an Apostolic-era Hebrew Matthew or a very early Hebrew translation of a Greek Matthew. In ShemTov's Matthew Jesus declares that his 'blood of the new [sic] covenant will be poured out (שיכך) for many'. The Hebrew verb that denotes the pouring out is third person, masculine singular, imperfect (future) Niphal (reflexive, passive). Since Niphal commonly connotes a tolerative aspect of an action (something permitted to be done), its future time-sense in this passage emphasises that the permitted act has not yet occurred. ${ }^{18}$ As far as lexical meaning is concerned, it should be

${ }^{17} \mathrm{M}$. Silva notes that an author's or speaker's own preferences for associating a tense with a time-sense should be considered ('A Response to Porter and Fanning on Verbal Aspect', in Biblical Greek Language and Linguistics: Open Questions and Current Research, ed. S.E. Porter and D.A. Carson [Sheffield: JSOT, 1993] 74-89).

${ }^{18}$ Shem-Tov ben Isaac's Hebrew Matthew is in G. Howard, The Gospel of Matthew According to a Primitive Hebrew Text (Macon: Mercer, 1987; 2nd ed. 1995). Howard notes word plays in Matthew that are possible only in Hebrew (180-83, 195-201). W.L. Petersen's review casts doubt on Howard's suggestion that the Shem-Tov text may derive from the 'original' Hebrew Matthew (JBL 108 [1989] 722-26), but it does not undermine Howard's argument that Shem-Tov could be a first/secondcentury translation of the Greek Matthew. Some, like M. Black ( $A n$ Aramaic Approach to the Gospels and Acts [Oxford: Clarendon, 1967]), defend Aramaic as the language of Jesus, sayings sources, and protogospels; similarly M. Casey ('The Original Aramaic Form of Jesus' Interpretation of the Cup', JTS 41 [1990] 1-12) argues that the cup-citations were in Aramaic. Others, however, hold that Jesus and early sources used Hebrew. See, for instance, T.W. Manson, 'Gospel According to St. Matthew', in Studies in the Gospels and Epistles, ed. M. Black (Manchester: University Press, 1962) 68-104; M.H. Segal, Grammar of Mishnaic Hebrew 
noted that the verb is not rooted in $ך$ J which denotes a libation or drink-offering, nor in 3 ' which denotes the pouring out of a

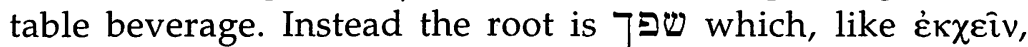
denotes indiscriminate gushing associated with sacrificial bloodshed. ${ }^{19}$ In Shem-Tov, the pouring out is unequivocally an act of violence.

Passages in the Torah confirm that it is appropriate for a Hebrew speaker to use the third-person, masculine singular, imperfect (future) Niphal of שפך when speaking of the pouring out of blood in atonement. In Leviticus 4:7-34 שיכך is used five times in prescribing how the Temple priest is to shed the blood of victims in atonement for the sins of priests, the community, princes, and private persons. Deuteronomy 19:10 also uses this tense in decreeing that cities of refuge be established so that the blood of the innocent 'shall not be shed'. Since the Septuagint does not use a participle in translating these passages, Synoptic use of $\dot{\varepsilon} \kappa \chi \cup v v o$ or $\varepsilon$ ov is not an attempt to bring the words of Jesus in line with the Septuagint.

Because the Greek participle used by the Synoptic authors in the cup-citations conveys time-sense through context, and because lexical meaning of this word (and its Hebrew equivalent in Shem-Tov) denotes indiscriminate sacrificial bloodshed rather than the offering of a libation, use of a future passive indicative, or even a passive infinitive in

(Oxford: Clarendon, 1991) 1-20; Reicke, Roots, 160-63; J.M. Grintz, 'Hebrew as the Spoken and Written Language in the Last Days of the Second Temple', JBL 79 (1960) 32-47; J. Carmignac, 'Studies in the Hebrew Background of the Synoptic Gospels', ASTI 7 (1970) 64-93; and C.S. Mann, 'Appendix', in J. Munck, Acts of the Apostles (Garden City: Doubleday, 1967) $315-16$.

${ }^{19}$ Another Hebrew verb denoting the pouring of a table beverage or libation is the intransitive 0 . Tפר ${ }^{\circ}$ is not associated with libations, beverages, or drink offerings is apparent in F. Brown, S.R. Driver, and C. Briggs, Hebrewv-English Lexicon of the Old Testament (Oxford: Clarendon, 1907) 650-51 and 1049-51. The tolerative aspect of Niphal is noted in Segal, Grammar, 59 (\#119) and in P. Joüon and T. Muraoka, Grammar of Biblical Hebrewv (2 vols.; Rome: Pontifical Biblical Institute, 1991) 1.149-51 (\#51). Use of a tense of שפכ in Shem-Tov's Mt. 26:28 more graphically denotes bloodshed than ערה) הערה in Is. 53:12. R.H. Gundry holds that $\dot{\varepsilon} \kappa \chi \varepsilon i v$ evokes Is. 53:12 (The Use of the Old Testament in St. Matthew's Gospel [NTS 18; Leiden: Brill, 1967] 59 n. 1). 
Latin or other languages correctly expresses the meaning intended by the Synoptic authors. But if they did intend to denote an action subsequent to the supper, the beneficiaries of the pouring out (those designated as 'you' or 'many') would not be affected by what 'is' taking place at the supper but by what 'shall' take place later. Thus reference to the beneficiaries of the pouring out is not an 'inclusive' reference to those who are invited to the supper and/or those who drink what Jesus offers. Instead, all that is implied regarding those who are designated as objects of the preposition is that a pouring out will take place for them and it will remit sins. The use of $\pi 0 \lambda \lambda$ oi by Matthew/Mark and the manner in which it is used both show that this is the more primitive designation of the beneficiaries and that the pouring out is an act of indiscriminate atonement, not an act that brings about inclusion in the supper.

To clarify this point, one must return to the debate between those who defend the accuracy of Luke's cup-citation and those who defend that of Matthew/Mark. An argument against the accuracy of Matthew/Mark has been their inclusion of 'blood of the covenant', which would not only be abhorrent in a reference to drinking but which, according to some scholars, is grammatically impossible in Hebrew and Aramaic. Nevertheless, the phrase 'blood of the covenant' is possible in Hebrew. This has not only been noted by defenders of Matthew's or Mark's priority but is also suggested by use of $\alpha i \mu \alpha \tau \bar{\eta} \varsigma \delta \imath \alpha \theta \dot{\eta} \kappa \eta \varsigma$ in the Septuagint of Exodus 24:8. The Hebrew text of Exodus 24:8 uses the word order דם הברית. Similarly, in Shem-Tov's Matthew 26:28, the wording is דמי מברית

${ }^{20}$ Kuhn argues that $\alpha \hat{\imath} \mu \alpha \dot{\alpha} \mu \nu \tau \hat{\jmath} \varsigma \delta \iota \theta \dot{\eta} \kappa \eta \varsigma$ is grammatically impossible in Hebrew or Aramaic ('Lord's Supper', 65-93). But the likelihood that 'blood of the covenant' rather that 'covenant in blood' would be used is noted by Gundry (Use of the Old Testament, 58 n. 3), Jeremias (Eucharistic, 193-95), and J.A. Emerton ('The Aramaic Underlying ' $\tau$ ò $\alpha i \mu \alpha$ ' $\mu$ ov $\tau \bar{\eta} \varsigma \delta \alpha \theta \theta \dot{\eta} \kappa \eta \varsigma^{\prime}$ in

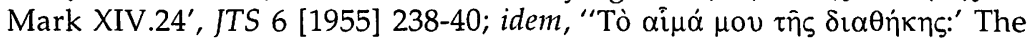
Evidence of the Syriac Versions', JTS 13 [1962] 111-17). Chilton notes the conformity of the wording of Matthew/Mark to the Septuagint rendering of Ex. 24:8 (Feast, 87). Although Ex. 24:8 does not refer to Passover bloodshed, it is associated in the Targum Pseudo-Jonathan with 'atonement for the people', not just the priest-elders who share the meal with Moses 
Consistency of Matthew's/Mark's blood-covenant reference with Hebrew phrasing counters the argument that their reference to beneficiaries of the covenant as 'many' is non-

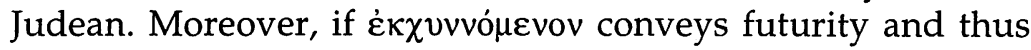
refers to what is spilled, not what is consumed, it is more logically followed by a third-person object (many) rather than a second-person object (you). ${ }^{21}$

In Biblical and Mishnaic Hebrew, as well as in Septuagint and New Testament Greek, a totality may be denoted by either $ב / \pi$ o $\lambda$ ú $\varsigma$ or $2 / \pi \hat{\alpha} \varsigma$. Hebrew texts, such as 1QH 4:28-29 and 2 Esdras 8:3,22 indicate by their context that denotes the entire human race, not just a portion of it. Micah 4:3 uses רבים and $\pi$ o every nation.23 Of course, רבים and $\pi$ o ${ }^{2} \lambda \lambda$ oí can denote part of a group or entity and, in Hebrew and Septuagint versions of Is. $52: 14-15,53: 11,12 a, 12 b$, indicates that those whose sins are borne by the Messiah are not כלנו / כאו $/ \pi$ d 53:6). Nonetheless, other Hebrew and Septuagint texts use רב/תoגús to denote all humanity (e.g., Ne. 13:26; Ps. 19:11; 29:3; 97:1; Ezk. 12:27). ${ }^{24}$

In the New Testament, $\pi$ o $\lambda \lambda$ oi often designates a group

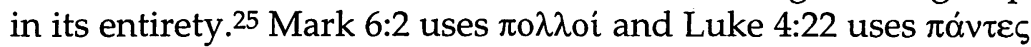
to denote an audience who are amazed by Jesus' words. That

in Ex. 24:11. See Grayston, Dying, 208; J.L. Ska, 'Le repas de Ex. 24:22', Bib 74 (1993) 305-27.

${ }^{21}$ Schürmann holds that Luke's use of a pre-Synoptic narrative is shown by his citation of 'for you' (Lukanischen, 2.75-77). Jeremias, who holds that Mark preserves a primitive source, argues that 'for many' is evidence of early eschatological concern (Eucharistic, 179-82). Marshall defends 'for many' on the basis that Matthew is an eyewitness record (Last Supper, 49). Lietzmann remarks that, although liturgical context lead to the inclusion of 'for you', its sense was 'for many' (Mass, 180). Shem-Tov uses 'rabbim' (Howard, Gospel, 134).

22The Hebrew original of 2 Esd. 8:3 probably read רבים are created, few are saved'.

23Jeremias, TDNT 6.536-45. Cf. M. Zerwick, 'Pro Vobis et Pro Multis Effundetur', Notitiae 53 (1970) 138-40.

${ }^{24}$ Other examples are proposed by L. Koehler and W. Baumgartner, The Hebrezv and Aramaic Lexicon of the Old Testament, ed. and trans. M.E.J. Richardson (3 vols.; Leiden: Brill, 1996) 3.1171.

25Moulton, Grammar, 26. 
God's anointed one gives his life as a ransom is described in Mark 10:45 as being $\dot{\alpha} v \tau i$ $\pi 0 \lambda \lambda \hat{\omega} \nu$ and in 1 Timothy 2:5-6 as $\dot{\tau} \pi \dot{\varepsilon} \rho$ $\pi \alpha \dot{v} \tau \omega v$. Although Hebrews 2:9, which declares that Jesus tasted death $\dot{v} \pi \dot{\varepsilon} \rho \pi \alpha \dot{v} \tau o \zeta$, is followed by Hebrews 2:10, in which $\pi 0 \lambda \lambda$ ov่ $\varsigma$ seems to refer only to that portion of the $\pi \dot{\alpha} \nu \tau \varepsilon \varsigma$ for whom Jesus' death brings salvation (cf. Heb. 4:6 and 10:26-28), other epistolary writings use $\pi \circ \lambda \lambda$ oi to designate the magnitude, not a portion, of the $\pi \dot{\alpha} v \tau \varepsilon \varsigma$. Thus Paul in 2 Corinthians 5.14-15 declares that Christ died i $\pi \dot{\varepsilon} \rho \pi \alpha \dot{v} \tau \omega v$, but in Romans 5:15 uses $\pi$ o $\lambda \lambda$ oi in asserting that all people die and also in designating those who are given a gift (not just those who are saved) by Christ. In both 1 Corinthians 10:17 and 10:33, $\pi \alpha \dot{v} \tau \varepsilon \varsigma$ are identified as $\pi 0 \lambda \lambda$ oí. $^{26}$

Such usage is not only consistent with the Hebrew use of $ר$ but also parallels classical authors who used the Attic $\pi 0 \lambda$ v́ $\varsigma$ or the Ionic $\pi 0 \lambda \lambda$ ó $\varsigma$ with an inclusive sense. Thus Hesiod's Opera et Dies 696 describes an undivided period of time as

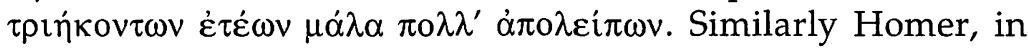
depicting the outstretched body of a fallen warrior ( $\pi \mathrm{o} \lambda \lambda \dot{\mathrm{o}} \varsigma$ [ $\gamma \alpha \dot{\alpha} \rho$

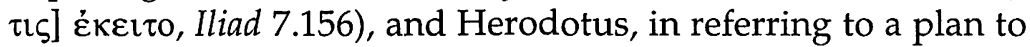

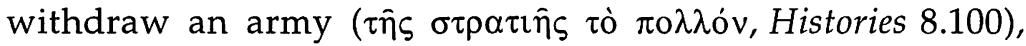
indicate by the context the totality of an effect. In several classical writings, oi $\pi 0 \lambda \lambda$ oi denotes not only 'the common people' apart from the rulers, officers and priests, but is used inclusively of an entire population. 27

Use of $\pi$ o $\lambda \lambda$ oi by Matthew/Mark is best illustrated by

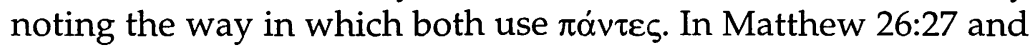
Mark 14:23, $\pi \alpha$ óv $\tau \varepsilon \varsigma$ designates an exclusive group: the Twelve who at the supper are told to 'drink all of you' (Matthew) or who are reported to have 'all drank' (Mark). This conforms to Hebrew usage in which an assembled group is referred to specifically by the words כ כא ('all'), and to the practice in many languages of addressing those present as 'all' ${ }^{28}$ In the

26Jeremias, TDNT, 6.539-40.

27Liddell, Scott, Jones, Lexicon, 1442-43.

28It is also possible that Matthew/Mark use $\pi$ o $\lambda$ hoi to mean 'all who are many', ass suggested by M. Zerwick and M. Grosvenor, Grammatical Analysis of the Greek New Testament (Rome: Pontifical Biblical Institute, 1974) 1.156. 
Greek text as well as Shem-Tov, Matthew's reference to those at supper as $\pi \alpha \dot{v} v \varepsilon \varsigma / \delta N$ is then followed by reference to $\pi 0 \lambda \lambda \circ$ i $/ 2$ as those for whom blood is shed. This distinction is consistent with use in Hebrew of רבים to designate those outside the כל. The root $ר$ can in some contexts mean 'many', but may also denote an unlimited number, a 'myriad'.29 Thus if Matthew/ Mark thought in Hebrew / Aramaic or worked with sources in these languages, $\pi \alpha$ ó $\tau \varepsilon \varsigma$ would in context of a Passover supper have an exclusive meaning but $\pi \circ \lambda \lambda o i$ in that same context would be inclusive.

From these observations, two principles for conceptualising and translating the cup-citations can be drawn.

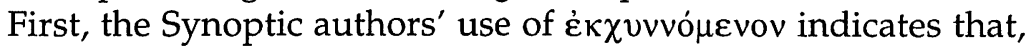
although they or the source they commonly preserve at this point assume that the cup's content is being poured out at supper as Jesus speaks, Jesus is cited as speaking of a 'tolerative' pouring out for beneficiaries. Shem-Tov's use of a Hebrew verb denoting sacrificial rather than meal-related outpouring and of a tense that connotes a future action supports the likelihood that the pouring out refers not to Jesus' action at supper but to his expected act the next day. Because the actual time-sense of a Greek participle depends less on grammatical tense than on aspect and context, use of a future tense in translation is lexically accurate.

Secondly, because $\pi \varepsilon \rho \dot{i} / \dot{v} \pi \dot{\varepsilon} \rho \pi 0 \lambda \lambda \hat{\omega} v$ is related to an anticipated act involving blood (whatever the identity of the cup's content), this prepositional clause refers to what comes about through the pouring out itself, not through participation in that act by accepting (either through free will or predestination) the supper offering. It is the redemptive act, not participation at a historical, liturgical, or eschatological supper, that is designated. Although this means that 'many' in Matthew/Mark has inclusive meaning, this is not sufficient argument for using 'all' in translation or liturgy. ${ }^{30}$ Since the citation preserved in Matthew/Mark does not use any of

${ }^{29} \mathrm{H}$. Preuss, TDOT 1.449-63. Is. 52:14 uses כל to designate an exclusive group and רב to refer to those who will be amazed by God, presumably all humanity. In Is. 53:6 an assembly who have gone astray are כל.

30Zerwick, 'Pro Vobis', 140. 
several Greek words for 'all', substitution of an equivalent for 'all' in rendering the citation would betray the historicity and Hebraic underpinnings of the wording in Matthew/Mark.

\section{Early Translations}

Although some standardised Latin texts (Erasmus, Beza, Nova Vulgata) suggest by using effunditur/funditur that Patristic

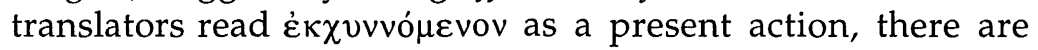
indications that Latin text copies with an ' $i$ ' rather than an ' $e$ ' in the verb result from copyists' errors rather than Patristic interpretations.

Among Old Latin texts that pre-date the ninth century, the fourth-century Vercellensis (a) and the fifth-century Cantabrigiensis (d) and Corbeiensis $2\left(\mathrm{ff}_{2}\right)$ contain effunditur in Matthew. The fourth-century Bobiensis (k), the fifth-century Cantabrigiensis (d), and the eighth-century Rehdigeranus (l) and Aureus (z) have effunditur in Mark. Since Old Latin texts, like Greek texts, sometimes omit Luke 22:19b-20, only Aureus contains funditur. Vulgate text copies from before the ninth century preserve the present passive in Matthew in $\mathrm{A}, \mathrm{B}, \mathrm{Be}, \mathrm{C}$, D, E, Ep, F, H, I J, K, L, M, Ma, O; in Mark in Sss, M, B*, Gc, Q; and/or in Luke in S, Ms, Ep, Cs.

Nevertheless, codices show that scribes who recorded the present tense in one Synoptic passage often recorded the future tense in others. In Vulgate texts, the seventh-century Amiatinus (A) and Dublinensis (D), which have effunditur in Matthew, have the future tense in Mark/Luke. The seventh/ eighth-century Kenanensis (Q) has the present tense in Mark but the future in Matthew/Luke, and the ninth-century Sangermanensis (G), which lacks Matthew, contains effunditur in Mark through a 'corrector'. Only two Old Latin texts, Latin Bezae (d) which has the present in Matthew/Mark and Aureus (z) which has the present in Mark/Luke, contain this tense in more than one Synoptic gospel. The Bobiensis (k), which by its early date suggests that effunditur in Mark records the Old Latin, lacks all of Luke and the relevant parts of Matthew. The Corbeiensis $\left(\mathrm{ff}_{2}\right)$, which has effunditur in Matthew, has effundetur in Mark and omits Luke 22:19b-20. Among Vulgate 
texts, only the sixth-century Epternacensis (Ep) and Mediolanensis (M), and the ninth-century Bambergensis (B) have the present tense in more than one Synoptic gospel. On the other hand, Old Latin texts such as the fifth-century Palatinus (e), sixth-century Brixianus (f), and seventh-century Monacensis (q) consistently use the future passive effundetur/ fundetur. The fourth/fifth-century Veronensis (b), which is effaced between Luke 22:18 and 22:21, has effundetur in Matthew/Mark. Likewise the fifth/sixth-century Sangellensis (n), which is missing all of Luke, has effundetur in Matthew / Mark, and the seventh-century Usserianus ( $\left.\mathrm{r}_{1}\right)$, which lacks Mark, uses the future tense in Matthew/Luke. The fifth-century Claromontanus (h), which contains only Matthew, and the seventh-century Vindobonensis (i), which preserves only Mark's cup-citation, record effundetur. Among Vulgate texts the sixth-century Claromontanus (U), which lacks Matthew, has the future tense in Mark/Luke. Likewise the seventh/eighthcentury Cantabrigiensis $(X)$ and Harleianus $(Z)$ consistently use the future tense. ${ }^{31}$

Since text-criticism of Old Latin and Vulgate manuscripts suggests but does not of itself prove that Jerome and the Old Latin translator/s used the future tense, one needs to turn to early commentaries for verification. In a work discussing his Vulgate, Jerome noted that, although he had seen Old Latin texts with funditur in Luke, he considered fundetur to be the correct rendering. Likewise, in an exegetical

\footnotetext{
${ }^{31}$ A. Merk, Novum Testamentum Graece et Latine (Rome: Pontifical Biblical Institute, 1957) 40-43, 95 n., 173 n., 289 n.; F.G. Kenyon, The Text of the Greek Bible (London: Duckworth, 1975) 92; H.F.D. Sparks, 'The Latin Bible', in The Bible in its Ancient and English Versions, ed. H.W. Robinson (1940; Westport: Greenwood, 1970) 100-27; and B. Fischer, 'Zur Überlieferung des lateinischen Textes der Evangelien', in Recherches sur l'histoire de la Bible Latine, ed. R. Gryson and P.-M. Bogaert (CRTL 19; Louvain: Faculté de Theologie, 1987) 51-104; idem, 'The Latin Versions', in The Early Versions of the New Testament, ed. B. Metzger (Oxford: Clarendon, 1977) 285-374. That Luke's cup citation in Veronensis is damaged, not omitted, is apparent in The Four Gospels from the Codex Veronensis (b), ed. E.S. Buchanan (OLBT 6; Oxford: Clarendon, 1911) 156.
} 
discussion, Jerome used effundetur in a citation from Matthew. ${ }^{32}$ Even though these commentaries make clear that Jerome understood the Synoptic Gospels as denoting a pouring out subsequent to the Last Supper, the question that remains is whether Jerome's preference for effundetur/fundetur reflected a Latin-speaker's misunderstanding of Greek usage. Although use of effunditur by Ambrose of Milan raises the possibility that some Church Fathers read the cup-citations as denoting a present pouring out, analysis reveals that Ambrose used effunditur not in translating the Greek or in citing a Latin gospel text, but in discussing what 'is being poured out' to contemporaries who receive the eucharist. Although Erasmus and later scholars, seeing effunditur in a commentary by Origen and in a liturgy attributed to Hippolytus, concluded that these Fathers understood the Synoptic Gospels as denoting a present action, it should be remembered that both Origen and Hippolytus composed in Greek and that surviving Latin texts of the commentary and liturgy record the rendering of postPatristic translators. 33 Syriac versions of the Synoptic Gospels from the third century and later use a present participle in translating the Greek, but since this Syriac verb-form can denote a future as well as a present action, Syriac texts provide no insight into early interpretations of the Greek. In third/ fourth-century Coptic texts, however, where a choice would have to be made concerning the time-sense of $\dot{\kappa} \chi \nu v v o ́ \mu \varepsilon v o v$, all versions in all dialects use the future tense. ${ }^{34}$

${ }^{32}$ Codicum Divinae bibliothecae Variantes Lectiones (Migne, PL 29.1055) and Commentariorum in Evangelium Matthaei, 4.26 (Migne, PL 26.195).

${ }^{33}$ Origen, Commentariorum Origenis in Matthaeum (Migne, PG 13.1736). The Latin text of Hippolytus is in Lietzmann, Mass, 34. Cf. Ambrose, In Psalmum CXVIII Expositio (Migne, PL 15.1505) and In Psalmum XXXVII Enarratio (Migne, PL 14.1017). See R. Johanny, L'Eucharistie Centre de l'histoire du salut Chez Saint Ambroise de Milan (Th 9; Paris: Beauchesne, 1968) 139-47. John Chrysostom's homily on Matthew cites $\dot{\varepsilon} \kappa \chi u v v o ́ \mu \varepsilon v o v$ but is translated as effundetur (Migne, PG 58.757). Cf. Erasmus, Annotationes in Novum Testamentum (Basle, 1516) 2.90.

${ }^{34}$ S.P. Brock, 'Limitations of Syriac in Representing Greek', in Early Versions, 90-91; The Coptic Version of the New Testament in the Northern Dialects, ed. G. Horner (4 vols.; reprint of 1898-1905; Osnabruck: Zeller, 1969); and The Coptic Version of the New Testament in the Southern Dialects, ed. G. Horner (7 vols., reprint of 1911-24; Osnabruck: Zeller, 1969). 


\section{Conclusion}

Although most modern vernacular translations, by rendering $\dot{\varepsilon} \kappa \chi \cup v v o ́ \mu \varepsilon v o v$ in the present tense, suggest that the Greek text of the Synoptic cup-citations denotes a pouring out taking place in the supper room, modern linguistic research undertaken apart from translation decisions or historical-critical analysis has

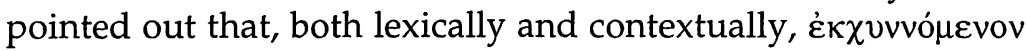
denotes an action that does not coincide with the drinking of a cup-offering. In other words, linguistic studies of the verbal aspect of present participles indicate that $\dot{\varepsilon} \kappa \chi v v v o$ ó $\varepsilon v o v$ was intended by those who transmitted a cup-citation in Greek as denoting the bloodshed of the crucifixion. Early Hebrew, Latin, and Coptic transmissions of the cup-citations reveal by their use of a future time-sense that Patristic-era Christians understood the pouring out as a reference to sacrifice rather than to libation. 